\title{
Calcium-creatinine ratio in a morning urine sample for the estimation of hypercalciuria associated with non-glomerular hematuria observed in children and adolescents
}

\author{
Susana Quiñones-Vázquez, María del Rosario Liriano-Ricabal, Sergio Santana-Porbén* and \\ José Reinaldo Salabarría-González \\ Department of Studies of Renal Function, Clinical Laboratory Service, Pediatric Teaching Hospital Juan Manuel Márquez, Havana, Cuba
}

\begin{abstract}
Background: Hypercalciuria might be revealed during the differential diagnosis of hematuria accompanying renal lithiasis (RL). Despite this, the diagnostic accuracy of urinary calcium excretion might be affected by incomplete 24-hour urine collections. In the present study, the diagnostic utility of calcium/creatinine index (ICaCre) for determining hypercalciuria associated with non-glomerular hematuria (NGH) and RL was assessed. Methods: ICaCre (mg/mg) index was calculated from calcium (mmol/I) and creatinine ( $\mu \mathrm{mol} / \mathrm{l})$ concentrations in an aliquot from a 24-hour urine collection in 169 children and adolescents with NGH or RL. Calciuria values $>4.0 \mathrm{mg} / \mathrm{kg} / 24$ hours were distributed according to the presence of NGH or RL. Results: Mean ICaCre index was $0.2 \pm 0.1 \mathrm{mg} / \mathrm{mg}$. Calciuria values estimated from ICaCre were statistically higher to those from 24-hour urine collection $(p<0.05)$. The frequency of hypercalciuria was independent from the measurement method (estimated from ICaCre: $39.5 \%$ vs. 24 h collection: $32.1 \%, p>0.05)$. Hypercalciuria distribution was as follows: No NGH + No RL: $59.0 \% ; n o ~ N G H+R L: 60.0 \%$ $(\Delta=+1.0 \%) ; N G H+$ No $R L: 68.2 \%(\Delta=+9.2 \%) ; N G H+R L: 73.3 \%(\Delta=+14.4 \%)$.Conclusions: The use of ICaCre for determining calcium urine excretion might be effective in the study of hypercalciuria associated with NGH and $R L$.
\end{abstract}

Key words: Hypercalciuria. Urine. Hematuria. Kidney lithiasis.

\section{Índice calcio-creatinina en una muestra matutina de orina para la estimación de hipercalciuria asociada con hematuria no glomerular observada en las edades infanto-juveniles}

\section{Resumen}

Introducción: La hipercalciuria suele revelarse durante el diagnóstico diferencial de la hematuria que acompaña la litiasis renal. La exactitud diagnóstica de la excreción urinaria de calcio puede afectarse por las insuficiencias asociadas con la colección de orina de 24 horas. En este estudio se evaluó la utilidad diagnóstica del índice calcio/creatinina (ICaCre) en la estimación de hipercalciuria asociada con hematuria y litiasis renal. Métodos: Se calculó el ICaCre de las concentraciones urinarias de calcio (mmol/l) y creatinina (mmol/l) en una alícuota de colección de 24 horas de orina en 169 niños y adolescentes atendidos por hematuria no glomerular (HNG) o litiasis renal (LR). La calciuria de 24 horas $>4.0 \mathrm{mg} / \mathrm{kg} / 24 \mathrm{horas} \mathrm{se}$ distribuyó según la presencia de HNG o LR. Resultados: El ICaCre promedio fue de $0.2 \pm 0.1 \mathrm{mg} / \mathrm{mg}$. La excreción urinaria

\section{Correspondence:}

*Sergio Santana-Porbén

E-mail: ssergito@infomed.sld.cu
Date of reception: 06-07-2017

Date of acceptance: 06-09-2017

DOI: 10.24875/BMHIME.M18000023
Available online: 12-07-2018 Bol Med Hosp Infant Mex. 2018;75:38-45 www.bmhim.com 
de calcio estimada del ICaCre fue significativamente superior a la obtenida en colección de orina $24 \mathrm{~h}(p<0.05)$. Los métodos de determinación de la calciuria concordaron en la frecuencia de hipercalciuria (ICaCre: 39.5\% vs. colección de 24h: $32.1 \%, p>0.05$ ). Según la presencia de HNG o LR, la hipercalciuria se distribuyó de la siguiente manera: No HNG + No LR: $59 \%$; No HNG + LR: $60 \%$ (diferencia: $+1.0 \%$ ); HNG + No LR: $68.2 \%$ (diferencia: $+9.2 \%$ ); HNG + LR: $73.3 \%$ (diferencia: $+14.4 \%$ ). Conclusiones: El ICaCre para estimar la excreción urinaria de calcio puede ser efectivo en el estudio de la hipercalciuria asociada con HNG y LR.

Palabras clave: Hipercalciuria. Orina. Hematuria. Litiasis renal.

\section{Introduction}

Hypercalciuria is a frequent finding among children and adolescents attending a nephrology service, due to non-glomerular hematuria or renal lithiasis ${ }^{1,2}$. However, it may have other causes, such as increased intestinal absorption of dietary calcium in response to vitamin $\mathrm{D}$ or parathyroid hormone (PTH) activity, primary hyperparathyroidism and renal tubular failure ${ }^{3,4}$. Idiopathic hypercalciuria $(\mathrm{IH})$ has been identified over decades as an important cause of increased urinary calcium excretion in the presence of preserved serum concentrations of this mineral ${ }^{4,5}$. Recently, a form of hypercalciuria has been described in the context of a "syndrome of excess PGE1 and PGE2 prostaglandins" ${ }^{\prime \prime}$, so the diagnostic and therapeutic connotations of hypercalciuria urge a discussion of the current state of the accuracy of urinary calcium determination.

The study of urinary excretion of a specific substance has always had the inherent difficulty of obtaining an "exact" urine collection; this is, one that is representative of the natural period in which excretion of the solute occurs ${ }^{7}$. Traditionally, this natural period refers to 24 hours in the life of a patient; therefore, estimation of a solute's urinary excretion entails collection of urine excreted throughout 24 hours $^{8}$. Currently, at most, only a third of 24-hour urine collections fulfill the conditions to describe them as "exact". Thus, notable biases are introduced in the estimation of the urinary excretion of a given analyte of interest and, by extension, the quality of the information that is delivered to the laboratory ${ }^{8,9}$.

A substance's index of excretion (IndEx, the quantity of a given substance in a urine sample taken at any moment of the day, once corrected for the co-excreted quantity of creatinine), may be accepted as a reliable estimate of the urinary excretion of that substance ${ }^{10}$. In virtue of it, the calcium-creatinine index (ICaCre) has been used for the diagnosis of hypercalciuria ${ }^{11,12}$. Similarly, the expected values of the ICaCre have been described for different pediatric populations ${ }^{13}$. However, this index has been regarded, at most, as a tool that is only applicable for analysis of the cases with an increased calcium excretion ${ }^{14}$. Therefore, the excreted quantities of this mineral should be adjusted to the duration of one day in the life of a given subject by performing a 24-hour urine collection test if an increased ICaCre is corroborated ${ }^{15}$.

The ICaCre constructed using a morning urine sample may be transposed to a reliable estimate of the urinary 24-hour calcium excretion (calciuria), once corrected to the height and body surface of the patient using an appropriate deterministic mode ${ }^{16}$. Production of an estimate of 24-hour calciuria from the ICaCre will also allow exploitation of a single cut point for the diagnosis of hypercalciuria, which will ensure the comparison of the analysis results of this condition conducted at different geographic locations.

In virtue of all the previously mentioned, the objective of this work was to determine the accuracy of a 24-hour calciuria when estimated from the ICaCre in a child or adolescent with non-glomerular hematuria.

\section{Methods}

A prospective, analytical study was conducted. Children and adolescents between 1 and 18 years of age that attended our institution with a diagnosis of non-glomerular hematuria and were admitted by the Department of Studies of Renal Function (DSRF) for a determination of urinary calcium excretion requested by the specialized ambulatory clinics of Nephrology, Urology and Nutrition, as well as hospital wards, were eligible to participate.

For every participant, gender (male/female), age, diagnosis of non-glomerular hematuria (present/absent), and renal lithiasis (present/absent) were registered, as well as height $(\mathrm{cm})$ and body weight $(\mathrm{kg})$. Non-glomerular hematuria was established as the presence of non-dysmorphic red blood cells in a morning urine sample and the absence of any symptoms of the glomerular diseases (such as edema, nephrotic range proteinuria, and arterial hypertension). 
Demographic, clinical, anthropometric and biochemical data from children and adolescents included in this study series were entered into the DSRF's digital records using the NEFROCALC application, built with Windows Office's Access software (Microsoft, Redmond, VA, USA) $)^{17}$.

\section{Urine sample collection}

A 24-hour urine collection was obtained from every patient. The patient's parents were instructed that the morning urine sample of the day of delivery be collected separately for the construction of the ICaCre. Subsequently, this sample was reintegrated to the 24-hour collection, once an aliquot was separated for biochemical measurements.

Urinary creatinine (UCre, $\mu \mathrm{mol} / \mathrm{l})$ and calcium (UCa, $\mathrm{mmol} / \mathrm{l}$ ) concentrations were determined using Jaffè's kinetic reaction method and with the formation of a colored complex with arsenaze III, respectively ${ }^{18,19}$, according to current local analytical procedures. The analytical methods employed were implemented within a COBAS autoanalyzer (Hoffman-La Roche, France).

\section{Determination of the observed excretion of a substance}

Twenty-four-hour urinary excretion of a substance was obtained from the quantities in the same urine collection:

Creatinine $(\mathrm{mg} / 24 \mathrm{~h})=$ UCre $(\mu \mathrm{mol} / \mathrm{l}) \times 0.113 \times$ volume $(\mathrm{l} / 24 \mathrm{~h}) \quad$ [1] Calcium $(\mathrm{mg} / 24 \mathrm{~h})=\mathrm{UCa}(\mathrm{mmol} / \mathrm{l}) \times 40 \times$ volume $(\mathrm{l} / 24 \mathrm{~h})$ [2]

\section{Calculation of the calcium-creatinine index}

Urinary concentrations of creatinine and calcium were used for the calculation of the ICaCre using the following equation:

$$
\text { ICaCre }(\mathrm{mg} / \mathrm{mg})=\frac{\mathrm{UCa}(\mathrm{mmol} / \mathrm{I}) \times 40}{\operatorname{UCre}(\mathrm{mmol} / \mathrm{I}) \times 0.113}
$$

\section{Estimation of the calcium urinary excretion}

Urinary calcium excretion was estimate using an propieraty equation developed in the $\mathrm{DSRF}^{16}$ :

Calciuria $(\mathrm{mg} / 24 \mathrm{~h})=\mathrm{ICaCre} \times 0.5 \times$ height $\times \mathrm{BS} \times 8.333[4]$

The terms used in the equation correspond to the following ICaCre: calcium-creatinine index; BS: body surface $\left(m^{2}\right)$. BS was calculated using the equation proposed by Dubois and Dubois ${ }^{20}$. On the other hand, the number 0.5 corresponds to a constant of proportionality that describes the endogenous production of creatinine in the child/adolescent. Likewise, the number 8.333 represents a constant of metric scaling used to convert units of the ICaCre to $\mathrm{mg} / 24 \mathrm{~h}$.

Urinary calcium excretion was classified as pathologically elevated if the measured/estimated calciuria was $>4.0 \mathrm{mg} / 24 \mathrm{~h}$. Estimated values of 24-hour calciuria using the $\mathrm{ICaCre}$ were disaggregated according to the presence of non-glomerular hematuria or lithiasis.

\section{Assurance of the quality of the 24-hour urine collection}

Completion of the 24-hour collection was graded as adequate using the equation developed by Ghazali et al.21,22

\section{Data processing and statistical analysis}

Data recovered from the patients included in this study series were reduced to statistics of location (mean), dispersion (standard deviation) and aggregation (absolute/relative frequencies, percentages), according to the type of variable. For this, a Windows Office Excel electronic spreadsheet was used (Microsoft, Redmond, VA, USA).

Twenty-four-hour values of calciuria were filtrated according to the completion of the 24-hour collection (adequate or inadequate) and the nature of the 24-hour calciuria (non-pathological or pathological).

The difference between the observed and predicted values for the 24-hour calciuria was examined using the test for comparison of paired means based on the Student's $t$ distribution ${ }^{23}$. Comparability between the observed and predicted values of 24-hour calciuria was estimated using linear regression techniques based on least squares ${ }^{23}$. The $r^{2}$ coefficient of determination was obtained as an indicator of the analytical accuracy of the predictive equation for 24 -hour calciuria. The slope $b$ of the line from the comparison of methods served to estimate the correspondence between both methods ${ }^{23}$.

The studies of method comparison were complemented with the construction of a Bland-Altman graph for the differences between the 24-hour calciuria measured from the urine collection and that estimated from the ICaCre. Control limits of $95 \%$ were constructed for the difference between values anticipating an adequate 24-hour urine collection. Estimated values within the control limits of the 24-hour calciuria were quantified.

Additionally, diagnostic concordance between the observed and predicted values of the 24-hour calciuria was examined using the McNemar test for paired 
Table 1. Demographic, clinical and anthropometric characteristics of the children and adolescents included in this study series

\begin{tabular}{|l|c|}
\hline Characteristic & $\mathbf{n}(\%)$ \\
\hline $\begin{array}{l}\text { Gender } \\
\text { Male } \\
\text { Female }\end{array}$ & $86(50.9)$ \\
\hline $\begin{array}{l}\text { Age (years) } \\
\text { Age group } \\
\text { Preschool (1-4 years) } \\
\text { Preadolescents (5-12 years) }\end{array}$ & $10.4 \pm 3.7$ \\
\hline Adolescents $(\geq 13$ years) & $7(4.1)$ \\
\hline Hematuria & $99(58.6)$ \\
\hline Renal lithiasis & $63(37.3)$ \\
\hline Height $(\mathrm{cm})^{*}$ & $37(21.9)$ \\
\hline Weight $(\mathrm{kg})^{*}$ & $20(11.1)$ \\
\hline BMI $\left(\mathrm{kg} / \mathrm{m}^{2}\right)^{*}$ & $142.4 \pm 19.1$ \\
\hline BS $\left(\mathrm{m}^{2}\right)^{*}$ & $38.2 \pm 14.5$ \\
\hline
\end{tabular}

BMI, body mass index.

${ }^{*}$ Mean \pm standard deviation Source: study records $(N=169)$.

observations based on the $\chi^{2}$ distribution and the Kappa test. At all moments, a significance level of $5 \%$ was used $^{23}$.

\section{Results}

Our study series was constituted by 169 children and adolescents that fulfilled our research inclusion criteria. Table 1 shows the demographic, clinical and anthropometric characteristics of the participants. As it can be observed, our study series had an even distribution of men and women. Mean age was $10.4+3.7$ years, with a predominance between 5 and 12 years of age. Hematuria presented in $21.9 \%$ of our study series. On the other hand, renal lithiasis presented in $11.1 \%$ of the studied children and adolescents. Mean BMI was 18.1 $+3.3 \mathrm{~kg} / \mathrm{m} 2$. Meanwhile, mean body surface was 1.2 $+0.3 \mathrm{~m}^{2}$.

Table 2 shows the characteristics of the measurements taken from the urine samples. The mean volume from the 24-hour urine collections was $923.3+$ $500.9 \mathrm{ml} / 24 \mathrm{~h}$. Twenty-four-hour creatinuria was $16.8+$ $8.0 \mathrm{mg} / \mathrm{kg} / 24 \mathrm{~h}$. Twenty-four-hour urine collections were adequate in $47.9 \%$ of the cases.

Twenty-four-hour calciuria, estimated with the equations [3] and [4], was significantly higher than the one measured in a 24-hour urine collection in every
Table 2. Biochemical characteristics of the determinations made from urine collections

\begin{tabular}{|c|c|}
\hline Characteristic & n (\%) \\
\hline Volume $(\mathrm{ml})^{*}$ & $923.3 \pm 500.9$ \\
\hline Creatinine $(\mu \mathrm{mol} / /)^{*}$ & $6740.2 \pm 3488.2$ \\
\hline Creatininuria $(\mathrm{mg} / 24 \mathrm{~h})^{*}$ & $638.6 \pm 405.1$ \\
\hline Creatininuria $(\mathrm{mg} / \mathrm{kg} / 24 \mathrm{~h})^{*}$ & $16.8 \pm 8.0$ \\
\hline Adequate collections & $81(47.9)$ \\
\hline Calcium $(\mathrm{mmol} /)^{*}$ & $3.3 \pm 2.4$ \\
\hline $\begin{array}{l}\text { Calciuria }(\mathrm{mg} / 24 \mathrm{~h} \text { ) measured from a } \\
\text { 24-hour collection* }\end{array}$ & $108.1 \pm \frac{84.8}{\frac{3}{3}}$ \\
\hline $\begin{array}{l}\text { Calciuria }(\mathrm{mg} / \mathrm{kg} / 24 \mathrm{~h}) \text { measured from a } \\
\text { 24-hour collection* }\end{array}$ & $3.0 \pm 2.3$ \\
\hline $\begin{array}{l}\text { Calciuria (> } 4.0 \mathrm{mg} / \mathrm{kg} / 24 \mathrm{~h} \text { ) measured from } \\
\text { a } 24 \text {-hour collection* }\end{array}$ & $129(76.3)$ \\
\hline $\begin{array}{l}\text { Ca/Cre index measured from a } 24 \text {-hour } \\
\text { collection* }\end{array}$ & $0.19 \pm 0.13$ \\
\hline $\begin{array}{l}\text { Calciuria (mg/24 h) estimated using the } \\
\text { propietary equation* }\end{array}$ & $135.9 \pm 98.7$ \\
\hline $\begin{array}{l}\text { Calciuria }(\mathrm{mg} / \mathrm{kg} / 24 \mathrm{~h} \text { ) estimated using the } \\
\text { propietary equation* }\end{array}$ & $3.8 \pm 2.6$ \\
\hline $\begin{array}{l}\text { Calciuria }(>4.0 \mathrm{mg} / \mathrm{kg} / 24 \mathrm{~h} \text { ) estimated } \\
\text { using the propietary equation* }\end{array}$ & $104(61.5)$ \\
\hline Mean \pm standard deviation Source: study records ( $N=$ & 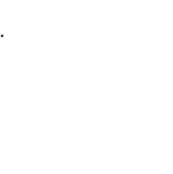 \\
\hline
\end{tabular}

collection [measured: $3.0 \pm 2.3 \mathrm{mg} / \mathrm{kg} / 24 \mathrm{~h}$ vs. estimated from the ICaCre: $3.8 \pm 2.6 \mathrm{mg} / \mathrm{kg} / 24 \mathrm{~h}(\Delta=-0.8$; $p<0.05$; paired-samples comparison test based on a Student's $t$ distribution). The smaller differences between the measured and estimated values for the 24hour calciuria were observed with adequate 24-hour urine collections [measured: $3.6 \pm 2.3 \mathrm{mg} / \mathrm{kg} / 24 \mathrm{~h}$ vs. estimated from the ICaCre: $3.3 \pm 2.3 \mathrm{mg} / \mathrm{kg} / 24 \mathrm{~h}$ $(\Delta=+0.3 ; p<0.05$; paired-samples comparison test based on a Student's t distribution)] and

inadequate collections [measured: $2.7 \pm 2.3 \mathrm{mg} / \mathrm{kg} / 24 \mathrm{~h}$ vs. estimated from the ICaCre: $4.0 \pm 2.9 \mathrm{mg} / \mathrm{kg} / 24 \mathrm{~h}$ $(\Delta=-1.3 ; p<0.05$; paired-samples comparison test based on a Student's $t$ distribution).

Figure 1 shows the comparability between the observed and predicted values of the 24-hour calciuria among the working analytical ranges. Observed values of the 24-hour were distributed between 6.6$493.4 \mathrm{mg} / 24 \mathrm{~h}(0.1-12.0 \mathrm{mg} / \mathrm{kg} / 24 \mathrm{~h})$. When adequate 24-hour urine samples were used, statistics for the line from the comparison of methods resulted as follows: $r^{2}$ 


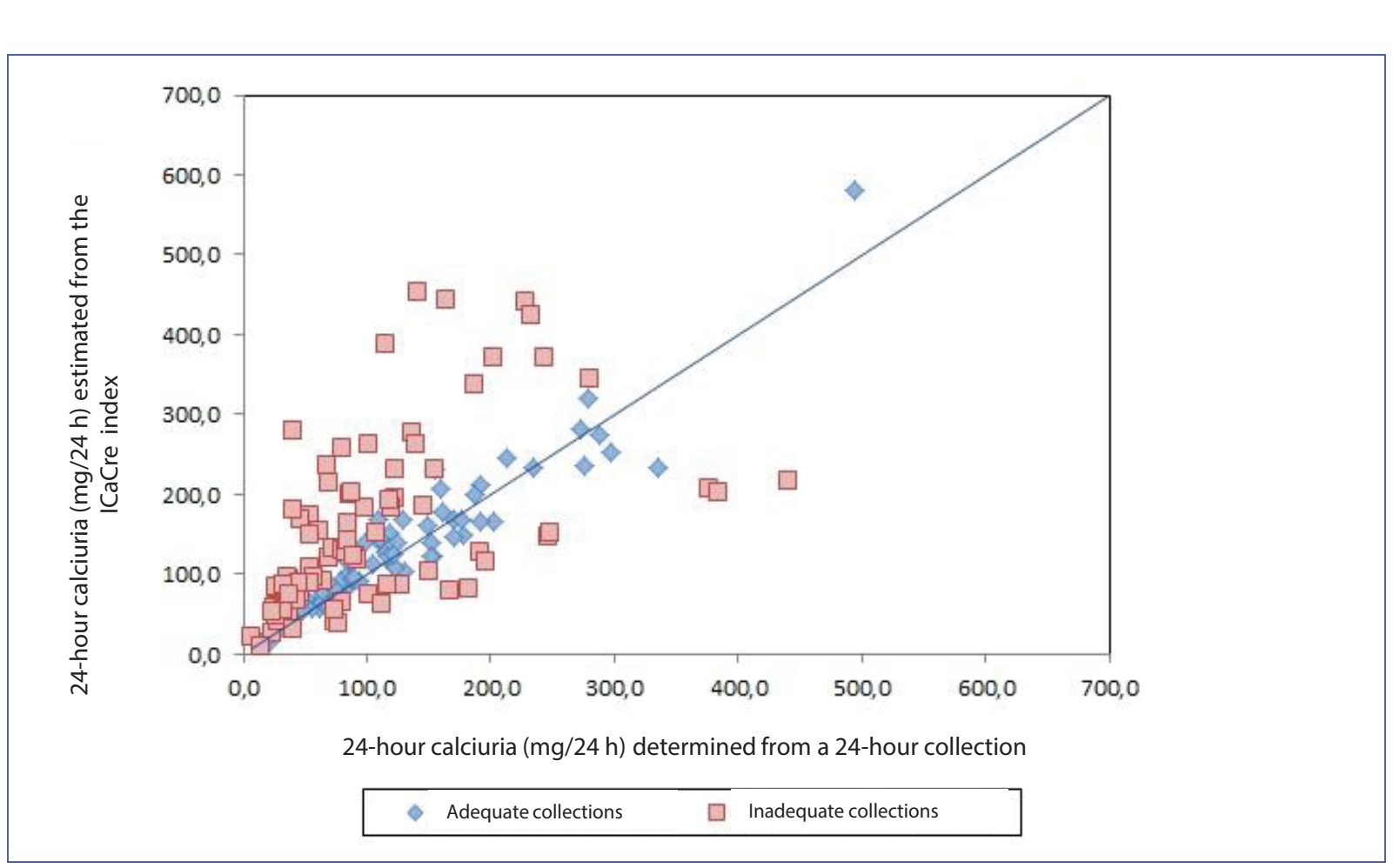

Figure 1. Relation between the 24-hour calciuria estimated using the proprietary formula developed in this work and that measured after a 24-hour urine collection. Line from the comparison of methods between the observed and estimated values of 24-hour calciuria. Adequate urine collection: estimated 24-hour calciuria $=9.3+0.97^{*}$ (observed 24-hour calciuria, $r^{2}$ coefficient $=0.91$; standard error of the regression $=26.0$ ) vs. inadequate collection: estimated 24 -hour calciuria $=79.8+0.69 *$ (observed 24 -hour collection, $r^{2}$ coefficient $=0.29$; standard error for the regression $=$ 90.3). In both instances, the probability of occurrence of the slope $p<0.05$.

coefficient: 0.91 ; standard error for the regression $=26.0$; intercept $a=9.3(p<0.05)$; slope $b=0.97$ $(p<0.05)$. The use of inadequate 24 -hour urine collections resulted in an increase of the inter-method inaccuracy: $r^{2}$ coefficient: 0.29 (difference from that obtained with adequate collections: $\Delta=-0.62$ ); standard error for the regression $=90.3(\Delta=+64.3)$; intercept $a=79.8(\Delta=+70.5)$; slope $b=0.69(\Delta=-0.28)$.

The relationship between the measured and estimated value for the 24-hour calciuria (absolute), as reflected through the Bland-Altman graphic is shown in figure 2. Inadequate urine collections introduced notable biases for the estimated value of the 24-hour calciuria: mean difference; adequate collections: $6.2+26 \mathrm{mg} / 24 \mathrm{~h}$ vs inadequate collections: $47.8 \pm 93.7 \mathrm{mg} / 24 \mathrm{~h}(\Delta=+41.6$; $p<0.05$; Student's t-test for the comparison of independent means). The differences introduced by the proprietary equation were of $22 \%$ in calciuria measured from a 24 -hour adequate collection. These reached $40 \%$ when the collection was inadequate.

The $95 \%$ limits for the differences between measured and estimated 24 -hour calciuria included $95.1 \%$ of the obtained results with adequate urine collection, but only $18.6 \%$ of those obtained from inadequate collections.

Table 3 shows the diagnosis concordance between the observed and predicted values. A diagnostic concordance of $87.7 \%$ was obtained (Kappa test $=0.73$; $p<0.05)$. The unconformities found did not reach statistical significance $\left(\chi^{2}=3.6 ; p>0.05\right.$; McNemar test for paired samples).

Finally, figure 3 shows the distribution of the 24-hour calciuria $>4.0 \mathrm{mg} / \mathrm{kg} / 24 \mathrm{~h}$ according to the patient's clinical condition and estimated from the $\mathrm{ICaCre}$ built from the morning urine sample using the developed proprietary equations. Thus, hypercalciuria presented in $61.5 \%$ of the studied children and adolescents. According to the clinical condition of the patient, the frequency of hypercalciuria had the following behavior: no hematuria + no lithiasis: $59.0 \%$ (difference with respect to the estimated for all causes: $\Delta=-2.5 \%$ ); no hematuria + lithiasis: $60.0 \%(\Delta=-1.5 \%)$; hematuria + no lithiasis: $68.2 \%(\Delta=+6.7 \%)$ and hematuria + lithiasis: $73.3 \%$ $(\Delta=+11.5 \%)$. 


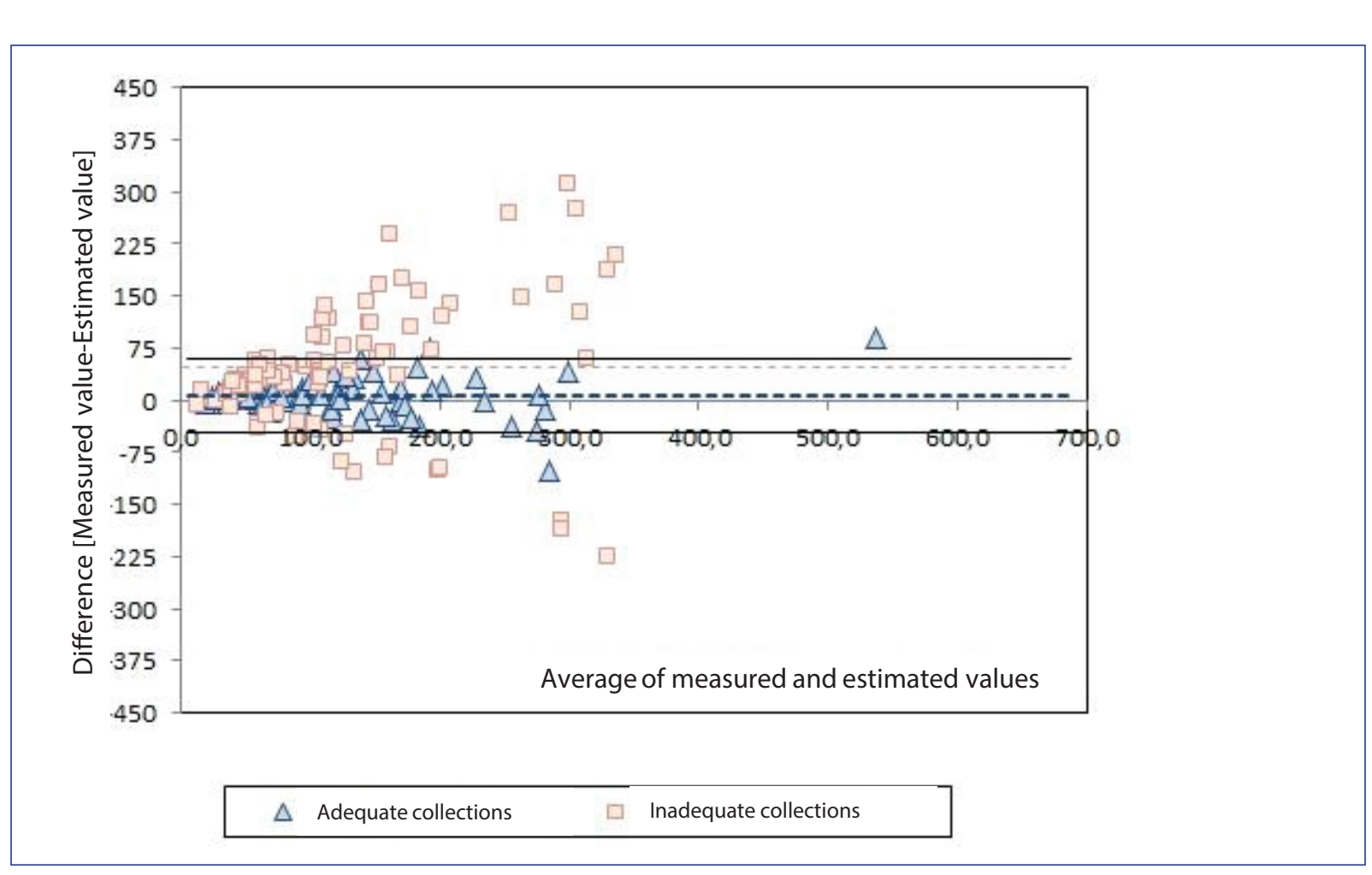

Figure 2. Blant-Altman graph for the concordance between the estimated 24-hour calciuria using a proprietary formula and that determined after a 24-hour urine collection. The continuous blue lines represent the $95 \%$ control limits for the difference between the estimated and measured values using adequate 24 -hour urine collections. Blue dotted line: the average of the obtained differences from the collections that were adequate. Red dotted line: an average of the obtained differences from the inadequate collections.

Table 3. Diagnostic concordance between calculation methods for the 24-hour calciuria

\begin{tabular}{|l|c|c|c|}
\hline Measured & \multicolumn{2}{|c|}{ Estimated } & Total \\
\hline & $>\mathbf{4 . 0}$ & $\leq \mathbf{4 . 0}$ & \\
\hline$>4.0$ & 24 & 2 & 26 \\
\hline 4.0 & 8 & 47 & 55 \\
\hline Total & 32 & 49 & 81 \\
\hline
\end{tabular}

$\chi^{2}=3.6(\mathrm{McNemar}$ test; $P>0.05) ; \mathrm{Kappa}=0.73(P<0.05)$. Source: study records

\section{Discussion}

This work examined the analytical, diagnostic and clinical usefulness of the $\mathrm{ICaCre}$ as an alternative to the 24-hour urine collection for the study of hypercalciuria with renal lithiasis. A previous study proved that the ICaCre index, adjusted to the children's height and the body surface, may serve to obtain reliable and reasonably exact estimates of the 24 -hour calciuria ${ }^{16}$. The use of the ICaCre could allow shortening of the latency period between the analysis and reports of the results while contributing to expediting and complementing the diagnostic processes that incorporate the 24-hour calciuria as a descriptor ${ }^{16}$.

When adequate 24-hour urine collections are ensured, the use of the ICaCre may offer values for urinary calcium excretion with an equivalence of $>95 \%$ and diagnostic accuracy of $>90 \%$. Moreover, the use of this index was distinguished by a diagnostic concordance of $>90 \%$, which ensures the interchangeability between the obtained results with the methods with which it was compared.

To the moment in which this study was written, the diagnostic process of $\mathrm{RL}$ has relied on obtaining a urine collection that is representative of a day in the life of the subject, to determine renal calcium excretion. Insufficiencies in the determination of the urinary renal excretion of specific substances in 24-hour urine collections are well-known ${ }^{24,25}$. Therefore, any alternative that derives exact values of the urinary excretion of a substance of interest and at the same time results in a 


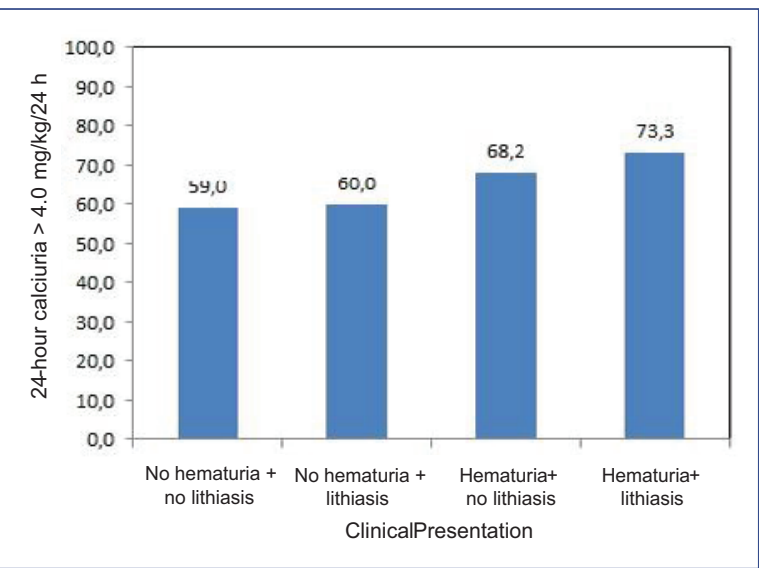

Figure 3. Distribution of hypercalciuria among the different clinical syndromes found in the series. Twenty-four-hour calciuria was estimated through the calcium/creatinine index built from a morning urine sample once adjusted to the child or adolescent height and body surface.

superior rate of completion of the diagnostic process will be useful ${ }^{26}$. Construction of the ICaCre with a morning urine sample and its conversion in an estimate of the 24-hour calciuria after the correction of the anthropometric characteristics of the child or adolescent would represent such an alternative, as it has been exposed in this article. Further research would be oriented to evaluating the cost-effectiveness of introducing a predictive equation to the dynamics of a laboratory, with vertical specialization in the study of renal function.

The present work has been extended to evaluate the presence of hypercalciuria in different clinical states such as non-glomerular hematuria and renal lithiasis. It must be pointed out that at the institution of the authors, an ambulatory consult operates which is vertically specialized in the diagnosis and treatment of renal lithiasis. Determination of the urinary calcium excretion is, therefore, a key analytical element of the hospital protocol for diagnosis of renal lithiasis. In this sense, in the study series that was built for this essay, the observed frequency of hypercalciuria was $61.5 \%$.

Hypercalciuria is highly prevalent in nephrolithia$\operatorname{sis}^{27,28}$, but many times it may be encountered in the absence of a recognizable cause for it. Hypercalciuria that is classified as idiopathic may affect $40.0 \%$ of children that attend a hospital Nephrology service with

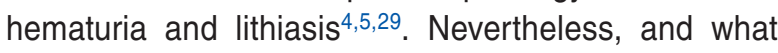
may constitute the most outstanding finding of this work, hypercalciuria presents in nearly three-quarters of children with hematuria and renal lithiasis, a finding that would add to other studies previously published ${ }^{5},{ }^{30}$. This way, the inclusion of the $\mathrm{ICaCre}$ in the diagnostic protocol for nephro-urological symptoms in children and adolescents, such as glomerular hematuria and renal lithiasis.

The predicted values for the 24-hour calciuria by using the ICaCre were comparable and correlated with those obtained after measuring a 24-hour urine collection. Diagnostic concordance was nearly $90 \%$. Hypercalciuria presented in $61.5 \%$ of this study series but affected $73.3 \%$ of children and adolescents with hematuria and lithiasis.

\section{Addendum}

A calculator that provides the calculations described in this work is available online at http://nefrocalc,sarhugo.com. For the interested reader, an application for mobile devices is also offered: http://nefrotoolbox.sarhugo.com/.

\section{Ethical disclosures}

Protection of human and animal subjects. The authors declare that no experiments were performed on humans or animals for this study.

Confidentiality of data. The authors declare that they have followed the protocols of their work center on the publication of patient data.

Right to privacy and informed consent. The authors declare that no patient data appear in this article.

\section{Conflicts of interest}

The authors declare no conflicts of interest.

\section{References}

1. Srivastava T, Alon US. Pathophysiology of hypercalciuria in children. Pediatr Nephrol. 2007;22:1659-73.

2. Velásquez Forero F, Esparza M, Salas A, Medeiros M, Toussaint G, Llach F. Risk factors evaluation for urolithiasis among children. Bol Med Hosp Infant Mex. 2016;73:228-36.

3. Levy F, Adams-Huet B, Pak CY. Ambulatory evaluation of nephrolithiasis: an update of a 1980 protocol. Am J Med. 1995;98:50-9.

4. Polito C, La Manna A, Cioce F, Villani J, Nappi B, Di Toro R. Clinical presentation and natural course of idiopathic hypercalciuria in children. Pediatr Nephrol. 2000;15:211-4.

5. Stapleton FB, for the Southwest Pediatric Nephrology Study Group. Idiopathic hypercalciuria: association with isolated hematuria and risk for urolithiasis in children. Kidney Int. 1990;37:807-11.

6. Velásquez Forero F, García P, Triffitt J, Llach F. Prostaglandin E1 increases in vivo and in vitro calcitriol biosynthesis in rabbits. Prostagl Leukotr Ess Fatty Acids. 2006;75:107-15.

7. Healy KA, Hubosky SG, Bagley DH. 24-hour urine collection in the metabolic evaluation of stone formers: Is one study adequate? J Endourol. 2013;27:374-8.

8. Caleffi A, Manoni F, Alessio MG, Ottomano C, Lippi G. Quality in extra-analytical phases of urinalysis. Biochem Med [Zagreb]. 2010;20:179-83. 


\section{S. Quiñones-Vázquez, et al.: ICaCre for the estimation of hypercalciuria associated with NGH}

9. Tormo C, Lumbreras B, Santos A, Romero L, Conca M. Strategies for improving the collection of 24-hour urine for analysis in the clinical laboratory: redesigned instructions, opinion surveys, and application of reference change value to micturition. Arch Pathol Lab Med. 2009:133:1954-60.

10. Gokce C, GokceG, BaydineC. Use of random urine samples to estimate total urinary calcium and phosphate excretion. Arch Intern Med. 1991:151:1587-8.

11. Parekh DJ, Pope JC, Adams MC, Brock JW. The association of an increased urinary calcium-to-creatinine ratio and asymptomatic gross and microscopic hematuria in children. J Urology. 2002;167:272-4.

12. Lavocat MP, Freycon MT, Muchrif M. Comparative study of 24-hour calciuria and urinary calcium/creatinine ratio in children over 4 years of age. Pediatrie. 1991;47:565-8.

13. Sargent JD, Stukel TA, Kresel J, Klein RZ. Normal values for random urinary calcium to creatinine ratios in infancy. J Pediatr. 1993;123:393-7.

14. Koyun M, Güven AG, Filiz S, Akman S, Akbas H, Baysal YE, et al Screening for hypercalciuria in schoolchildren: What should be the criteria for diagnosis? Pediatr Nephrol. 2007;22:1297-301.

15. Rath B, Aggarwal MK, Mishra TK, Talukdar B, Murthy NS, Kabi BC. Urinary calcium-creatinine ratio and hypercalciuria. Indian Pediatr. 1994;31:311-6.

16. Salabarría González JR, Santana Porbén S, Ricabal MDRL. Excreción urinaria de una sustancia predicha del índice sustancia-creatinina. Rev Latinoam Patol Clin Med Lab. 2015;62:119-26.

17. Santana Porbén S. Herramientas Informáticas para el Cálculo de los Indicadores de la Función Renal. In: Salabarría González JR, Santana Porbén S, editors. Laboratorio clínico y función renal. Madrid: Editorial EAE Académica Española; 2011.

18. Bartels $\mathrm{H}$, Cikes M. UeberChromogene der Kreatininbestimmung Nach Jaffé. [Chromogens in the creatinine determination of Jaffé]. Clin Chim Acta. 1969;26:1-10.
19. Michalylova V, Ilkova P. Photometric determination of micro-amounts of calcium with arsenazo III. Anal Chim Acta 1971;53:194-8.

20. DuBois $D$, DuBois EF. The measurement of the surface area of man [Fifth paper in a series]. Arch Intern Med (Chic). 1915;15:868-81.

21. Ghazali S, Barratt TM. Urinary excretion of calcium and magnesium in children. Arch Dis Child. 1974;49:97-101.

22. Counahan R, Chantler C, Ghazali S, Kirkwood B, Rose F, Barratt TM. Estimation of glomerular filtration rate from plasma creatinine concentration in children. Arch Dis Child. 1976;51:875-8.

23. Santana Porbén S, Martínez Canalejo H. Manual de procedimientos bioestadísticos. Madrid: EAE Editorial Académica Española; 2012.

24. Ulmann A. Predictive value of lithogenic risk in hypercalciuria: should 24-hour urine calcium be measured? Nephrologie. 1983;5:232-4.

25. Riess C, Hess B, Binswanger U. Questionable significance of the chemical analysis of a single 24-hour urine sample in recurrent calcium oxalate nephrolithiasis. Klinische Wochenschrift. 1986;64:411-6.

26. Ring $E$, Borkenstein $M$. Use of the calcium-creatinine ratio in diagnosis and therapy. Padiatr Padol. 1987;22:245-50.

27. Matsushita K, Tanikawa K. Significance of the calcium to creatinine concentration ratio of a single-voided urine specimen in patients with hypercalciuricurolithiasis. Tokai J Exp Clin Med. 1987;12:167-71.

28. Milliner DA. Urolithiasis. In: Avner ED, Harmon WE, Niaudet $P$, editors. Pediatric Nephrology. Philadelphia: Lippincott Williams \& Wilkins; 2004. pp. 1091-111.

29. Escribano J, Balaguer A, Martin R, Feliu A, Espax R. Childhood idiopathic hypercalciuria. Scand J Urol Nephrol. 2004;38:422-6.

30. Stapleton FB, Roy III S, Noe HN, Jerkins G. Hypercalciuria in children with hematuria. N Engl J Med.1984;310:1345-8. 